\title{
EFFECT OF GESTATIONAL STATE ON THE METABOLISM OF COWS IN THE REGION OF TIARET, ALGERIA
}

\author{
Berrani Abdelkader $^{1 *}$, Meliani Samia ${ }^{1}$, Bourabeh Akila ${ }^{2}$ \\ ${ }^{1 *}$ University of Tiaret, Nature and Life Sciences Faculty, Animal Hygiene \\ and Pathology Laboratory, (14000), Algeria; \\ ${ }^{2}$ University of Tiaret, Veterinary Sciences Institute, (14000), Algeria; \\ "Corresponding Author Berrani Abdelkader, e-mail : kadibiovet@gmail.com;
}

Received July 2021; Accepted August 2021; Published September 2021;

DOI: https://doi.org/10.31407/ijees11.428

\begin{abstract}
The aim of this study was to determine the influence of gestational state on certain biochemical parameters in Holstein crossbred cows reared in the region of Tiaret, Algeria. One hundred cows, during the year 2020-2021, aged from one year to ten years in different physiological stages were used. The animals belong to different farms in Tiaret located in the north-west of Algeria. The physiological state of the cows had a significant influence $(\mathrm{p}<0,05)$ on cholesterol, triglycerides, urea, total protein, albumin, calcium and phosphorus. We found that changes in concentrations and phenomena of metabolic adaptations and regulations were installed, in particular in the transition stage (gestation-lactation) and that the transition period is a major stressor on the cows studied. The results of this study could serve as reference values for this cows in the region of Tiaret, Algerian and other regions or countries with similar climatic and nutritional conditions.
\end{abstract}

Key words : cows, pregnant, postpartum, lactation, biochemical parameters. 